\title{
Investigation of different pre-treatments of chromium leather shavings to improve biogas production
}

\author{
Carolina Scaraffuni Gomes ${ }^{1 *}$ D, Jens-Uwe Repke ${ }^{2}$ and Michael Meyer ${ }^{1}$
}

\begin{abstract}
Chromium shavings are wet by-products of the leather industry, of which thousands of tons accrue worldwide during leather manufacture. Due to their chromium content, chromium shavings are responsible for the most important ecological challenges caused by the leather industry. They are stable towards temperatures of up to $110^{\circ} \mathrm{C}$ and enzymatic degradation. This high stability is caused by the three-dimensional native structure, typical for collagen, and additional chemical cross-links between the collagen fibres achieved by $\mathrm{Cr}^{3+}$ salts in the tanning process. Therefore, hitherto chromium shavings are not utilized industrially to produce biogas. In order to generate biogas, this stable structure has to be denatured. Chromium shavings were pre-treated by extrusion and hydrothermal methods. To prove the enzymatic degradability, the different pre-treatments were evaluated by differential scanning calorimetry (DSC), enzymatic assays, and by measuring the solubility in water. The biogas production potential was investigated using batch trials to examine feasibility. Results demonstrated that both pretreatments allowed enzymatic attack and increased degradability of the chromium shavings reducing the lag-phase of biogas production and the remaining waste.
\end{abstract}

Keywords: Biogas production, Anaerobic digestion, Chromium shavings, Extrusion, Hydrothermal treatment

\section{Introduction}

The leather industry plays an important role in the global biological material cycle, since its main raw material, the hide, is a by-product of the meat industry. In 2018, 128,760 tons of bovine hides were produced in Germany [1]. It is estimated that the production of one ton of leather is coupled with the quantity of $100 \mathrm{~kg}$ of tanned trimmings and shavings [2]. About $90 \%$ of all leathers worldwide are chromium tanned [3]. Therefore, most of this waste will contain $\mathrm{Cr}^{3+}$ and need special treatment. Currently, in most cases the chromium leather waste is disposed of through landfill despite the possible ecological consequences [4].

\footnotetext{
* Correspondence: carolina.scaraffunigomes@filkfreiberg.de

${ }^{1}$ Forschungsinstitut für Leder und Kunststoffbahnen (FILK) gGmbH, Meißner Ring 1-5, 09599 Freiberg, Germany

Full list of author information is available at the end of the article
}

Increased environmental restrictions and escalating landfill costs have encouraged the leather industry to minimize waste and to maximize its reuse [5]. Attempts to replace the chromium in the tanning process lead to higher production costs. Furthermore, chromium-based tanning is the most robust and cost-effective way to produce leather. It is possible to use vegetable agents in the tannery process, but those tanning agents cannot be considered as more environmentally friendly than chrome tanning [6]. Tannins are plant based phenolic compounds, which cause environmental problems due to their recalcitrant nature [7]. Glutaraldehyde is used as well, but the process is more complicated to perform and economically disadvantageous for tanneries [8]. Therefore, the leather industry continues to face the handling and disposal problems of chromium-containing waste.

\section{Springer Open}

(- The Author(s). 2020 Open Access This article is licensed under a Creative Commons Attribution 4.0 International License, which permits use, sharing, adaptation, distribution and reproduction in any medium or format, as long as you give appropriate credit to the original author(s) and the source, provide a link to the Creative Commons licence, and indicate if changes were made. The images or other third party material in this article are included in the article's Creative Commons licence, unless indicated otherwise in a credit line to the material. If material is not included in the article's Creative Commons licence and your intended use is not permitted by statutory regulation or exceeds the permitted use, you will need to obtain permission directly from the copyright holder. To view a copy of this licence, visit http://creativecommons.org/licenses/by/4.0/. 


\subsection{Anaerobic digestion of chromium leather waste}

Biogas production through anaerobic digestion of the chromium leather waste has the ability to reduce the final amount of waste and simultaneously to generate renewable energy. Moreover, it presents low level of process complexity and low cost. Hitherto, only a few studies on this subject were published. They demonstrate that it is possible to produce biogas from chromium leather waste but very long periods of time are needed for digestion.

Anaerobic digestion of organic matter is a quite complex microbial process that takes place in the absence of oxygen with many types of bacteria and archaea $[9,10]$. This process can be divided into four phases - hydrolysis, fermentation or acidogenesis, acetogenesis, and methanogenesis. In the hydrolysis, exoenzymes of hydrolytic bacteria break down polymers into monomers. In the acidogenesis, fermentative bacteria ferment the resultant monomers from the hydrolysis into acetic acid, hydrogen, carbon dioxide and volatile fatty acids. In the acetogenesis, acetogenic bacteria convert the fermentative intermediates (volatile fatty acids) into methanogenic substrates, hydrogen, carbon dioxide, acetic acids and unicarbon compounds. Finally, in the methanogenesis, methanogenic archaea convert the products of the acetogenesis into biogas, which is a mixture of methane (55-70\%), and carbon dioxide (30-45\%) with traces of other gases [9].

In the leather industry, most contributions focus their efforts on the digestion of more simple waste. Digestion of untanned fleshings was studied by Shanmugam and Horan [11], whereas digestion of sludge from wastewater treatment was investigated by Kameswari et al. [12], and digestion of wastewater by Banu and Kaliappan [13]. Codigestion of fleshings along with sludge was studied by Kameswari et al. [14] using pre-treated sludge, by Kameswari et al. [15] using different substrate to inoculum ratios, by Thangamani et al. [16] and Kameswari et al. [17] optimizing mix proportions of the substrates, and by Kameswari et al. [18] using multiple feeds of substrate. Finally, Ravindranath et al. [19] showed that codigestion of fleshings along with wastewater results in higher biogas yields than digestion of wastewater alone, and Thangamani et al. [20] verified that co-digestion of fleshings and wastewater was important to minimize ammonia toxicity.

Leather is composed of organic matter. Hence, it can be used as raw material for producing biogas, but tanned collagen is slowly biodegradable because of its stability. The natural collagenous structure of hides in connection with the treatment they undergo to produce leather with different chemicals (tanning process) makes them a stable material. This approach would become more feasible if it was possible to develop a simple and efficient method to reverse the effects of tanning [3].
Furthermore, there is the concern that the chromium present in the leather could be toxic for the anaerobic bacteria and archaea and inhibit the production of biogas and methane. Alkan et al. [21] studied the presence of chromium during anaerobic digestion testing the injection of $\mathrm{Cr}^{3+}$ ions in anaerobic digesters in batch tests, and concluded that an injection of $500 \mathrm{mg} \mathrm{L}^{-1}$ of $\mathrm{Cr}^{3+}$ was necessary to lead to a system failure.

Dhayalan et al. [22] and Ferreira et al. [23] studied the anaerobic digestion of chromium leather. The former concluded that degradation of the waste is possible using anaerobic sludge, which however is a very slow process and leads to low biogas amounts. The latter found that the results are dependent on the anaerobic sludge concentration and on the origin. Agustini et al. [24] also studied the anaerobic digestion of chromium leather and detected $55 \%$ of methane in the produced biogas. Priebe et al. [25] found a low performance of this waste to generate biogas and associated this to the saturation of the reactive sites due to chromium bonding and low water solubility. More recently, Agustini et al. [26] concluded that a scale-up of the process ( $300 \mathrm{~mL}$ to $2.5 \mathrm{~L}$ digesters) can increase biogas yields and destruction of organic matter. In all cases, the experiments were batch tests which lasted one to four months, and in most of the studies more than ten days were needed to start the biogas production. Regarding the chromium content, these previous studies found low concentrations of chromium in the bioreactors $[25,26]$, below toxicity limits. Chromium stemming from the chromium leather waste is diluted in the sludge. Therefore, inhibition of the anaerobic bacteria and archaea in batch reactors using chromium leather waste is not expected.

Therefore, the treatment processes for chromium shavings have to be simple and easy to perform. Furthermore, it should be economically advantageous. The pretreatment costs should be compensated by the energy gains. However, the reduction of the final waste, the disposal of which otherwise would generate costs, makes this method very attractive. Anaerobic digestion of chromium shavings for producing biogas appears to be economically and environmentally advantageous, but costly separation processes to remove chromium prior to digestion have to be prevented. To make the industrial use of chromium shavings for producing biogas feasible, it is important to reduce the digestion time and the remaining waste. Preliminary studies of biogas production with pre-treated chromium shavings have been performed by Gomes et al. [27] and showed that it was possible to increase efficiency of the process.

\subsection{Collagen structure and stability}

Wool-like chromium shavings are waste generated during leather making which accrues while adjusting the 
thickness of hides that have been tanned [28]. This waste mainly consists of the collagen of hide with complex bound $\mathrm{Cr}^{3+}$ salts and some residues from the tanning process (fat, salts, or mineral compounds).

Collagen molecules have in common that they are composed of three polypeptide chains which form a triple helical arrangement in the core of the structure. Each of the chains mainly consists of the amino acid triplets Gly-X-Y, where $\mathrm{X}$ and $\mathrm{Y}$ can be any amino acid [29]. This typical sequence leads to a triple helical structure of the collagen molecules. Hydrogen bonds and a few natural cross-links stabilize this arrangement resulting in high resistance to heat and bacterial degradation, and low solubility in aqueous buffers. Furthermore, the collagen molecules arrange into fibrils and fibres and, subsequently, different kinds of tissues [30].

Despite the natural stability of collagen, there is a need to further stabilize collagen fibres to produce leather by chemical cross-links [31]. These cross-links first of all have to prevent the collagen structure from collapsing during drying. They separate the molecules which would otherwise glue together resulting in stiff parchment. Furthermore, crosslinking also increases mechanical strength in wet state, provides a higher denaturation temperature, and lower susceptibility to enzymatic degradation [31]. The chemical crosslinking process applied to hides is known as the core of the leather manufacturing process but it prevents degradation of collagen by enzymatic methods.

\subsection{Destabilization of chromium leather waste}

Most of the research concerning the pre-treatment of substrates for biogas production addressed mechanical pre-treatments (33\%), such as ultrasound and extrusion, followed by thermal pre-treatments (24\%), such as steam explosion and autoclave and chemical pre-treatments (21\%) [32]. Mechanical pre-treatments are able to reduce particle size and, consequently, increase the specific surface available to the medium, which could improve gas production and lead to more rapid digestion [33]. Furthermore, pre-treatments help to breakdown complex polymers into smaller molecules promoting hydrolysis [34], the stage responsible for limiting the rate of degradation. The main goal is to render a more biodegradable substrate to the digestion process thus increasing methane production [32].

Thanks to their stable structure, collagen molecules are not susceptible to rapid degradation by enzymes, and the tanning process further increases their stability. However, anaerobic digestion can only start with the enzymatic degradation in the hydrolysis. To speed up the process, a pre-treatment to perform a prior denaturation of the triple helical structure is necessary. This can be accomplished by heating, leading to the collapse of the collagen structure into single protein chains. The random structure of these chains loses the former high stability and can be easily degraded. The denaturation temperature of chromium shavings attains $105^{\circ} \mathrm{C}$ to $110^{\circ} \mathrm{C}$, which requires a denaturation process at these temperatures [35].

Some studies were published on the pre-treatment of collagen. Klüver and Meyer [36] successfully performed extrusion to denature untanned bovine pelts in order to convert collagen into a thermoplastically processable biopolymer. Pillai and Archana [37] and Katsifas et al. [38] concluded that the previous autoclaving of chromium leather shavings was essential for the degradation by microorganisms.

As mentioned before it is possible to separate collagen from chromium performing an alkaline hydrolysis of the material. In some studies chromium leather waste was hydrolysed with alkaline solutions prior to anaerobic digestion. A Patent [39] claims to accelerate the start of the biogas production solubilizing chromium leather waste in an alkaline solution ( $\mathrm{pH}$ of 10 to 14 ) at $70{ }^{\circ} \mathrm{C}$ prior to anaerobic digestion in thermophilic conditions. Pati and Chaudhary [40] separated collagen hydrolysate and chromium by alkaline hydrolysis. It was possible to use the hydrolysate for producing biogas and to reuse the extracted chromium in the tanning process.

Therefore, a pre-treatment prior to anaerobic digestion can denature the chromium leather waste and start hydrolysis of the material in order to ease anaerobic digestion and improve the biogas production. However, there are conflicting results about the use of pre-treatments. Agustini et al. [41] tested the previous autoclaving of chromium leather shavings in order to enhance biogas production and showed that the pre-treatment was very aggressive, inducing sterilization and excessive degradation of organic matter. They concluded that the absence of thermal pre-treatment was more suitable for anaerobic digestion in this case.

The aim of the present study was to investigate different pre-treatment methods for denaturation of the collagen structure in a fast and efficient way, which can then easily be adjusted to industrial scale. Therefore, two established industrial techniques - extrusion and hydrothermal treatment - were selected which allow to achieve sufficiently high temperatures in a short time. These techniques work continuously and allow to treat wool-like fibrous materials such as shavings. They denature the collagen structure of the chromium shavings and improve biogas production without extracting chromium.

\section{Material and methods}

To investigate the success of the pre-treatments with regard to the biogas formation potential, three different 
steps were carried out. At first, chromium leather shavings underwent pre-treatment to initiate its material degradation. Secondly, the pre-treated samples were assessed regarding their degradation degree, i.e. the part of the sample that is already available for producing biogas when the anaerobic digestion starts. The degradation degree was measured using different fast in vitro methods, e.g. enzymatic degradability and calorimetric analyses. Finally, the biogas production of the samples was investigated through biogas production trials in order to prove the feasibility of the pre-treatments considered.

\subsection{Material}

Chromium-tanned leather shavings samples from the shaving operation of the leather-making process were obtained from a local tannery (HEWA Leder, Freiberg, Saxony, Germany). As reference for the biogas trials, bovine hide gelatin ( $260 \mathrm{~g}$ Bloom, type B) kindly supplied by Gelita AG (Eberbach, Germany) was used. Gelatin is denatured collagen and chemically the same as collagen only differing in the structure. Gelatin is known to be easily degraded by enzymes.

Samples were characterized regarding their water content [42], inorganic matter [43], chromium oxide content [44], and collagen content through the determination of hydroxyproline [45]. Experiments were run in triplicate. Usually, processed chromium shavings show water contents of around $50 \%$ but those used in this work had already been air-dried to some extent and have a water content of almost $20 \%$.

\subsection{Pre-treated samples}

Chromium shavings were pre-treated in order to denature the collagen structure. As a consequence, there is an increase in the part of the sample that is already available for producing biogas and an improvement in the biogas production.

\subsubsection{Pre-treatments}

Extrusion, a classical technique from the polymer industry, and continuous hydrothermal treatment which is commonly used to plastify wood for the manufacture of wood fibre boards [46], were used to pre-treat and denature the chromium shavings. Both are established industrial methods to treat synthetic and natural polymers. While extrusion affects the material by heat, mechanical shear, and pressure, the hydrothermal treatment is only based on heat and the corresponding steam pressure. Process aim is to achieve a temperature higher than the denaturation temperature of $105^{\circ} \mathrm{C}$ to $110^{\circ} \mathrm{C}$.

2.2.1.1 Extrusion Extrusion was performed with a corotating twin-screw-extruder Werner \& Pfleiderer ZSK
25 under different temperature $\left(100{ }^{\circ} \mathrm{C}, 130^{\circ} \mathrm{C}, 150^{\circ} \mathrm{C}\right.$, and $170^{\circ} \mathrm{C}$ ) and humidity conditions (dry or wet) in a continuous process. Prior to that, the wet chromium shavings were moistened with water $(60.1 \%$ water content), well homogenized and left overnight, in order to represent processed chromium shavings. The dry samples (19.7\% water content) represented chromium shavings, which were air-dried.

The extrusion process starts by feeding chromium shavings from a hopper into the barrel of the extruder. Subsequently, the structure of the material is gradually broken into small pieces by mechanical energy generated through turning screws, and the collagen molecules are denatured by heaters arranged along the barrel. The conversion of mechanical energy into heat makes it possible to use this process even below the denaturation temperature of chromium shavings $\left(105^{\circ} \mathrm{C}\right.$ to $\left.110^{\circ} \mathrm{C}\right)$. The process takes approximately 3 minutes.

The samples, which originated from dry and wet chromium shavings, differ in appearance. Extrusion of dry chromium shavings led to powdered samples, whereas extrusion of wet chromium shavings resulted in samples with granular shape. A high water content opens up the structure of the sample increasing the space between the fibres. This eases extrusion and enables formation of small grains of leather. If leather having a low water content is extruded, the fibres are close to one another. Consequently, when the leather structure was broken using mechanical force, the pieces of leather became very small and a powder was generated.

2.2.1.2 Hydrothermal treatment The chromium shavings were subjected to hydrothermal treatment using a continuous autoclave system attached to a refiner (Andritz $\mathrm{CPH}$ 12-1) at the Institut für Holztechnologie (Dresden, Germany). Usually, this equipment is used to refine wood but it is also adequate to process a variety of organic materials. The process was carried out under different temperature and pressure conditions in saturated steam. The material was dosed to a digester in which it was denatured with steam under pressure. The temperature was adjusted regarding the saturated steam relative pressure to $140^{\circ} \mathrm{C}(2.2 \mathrm{bar}), 150^{\circ} \mathrm{C}$ (3.8 bar), and $170^{\circ} \mathrm{C}(7 \mathrm{bar})$. The pre-treatment time was approximately $45 \mathrm{~s}$.

The samples were also different in appearance. Those pre-treated at $170{ }^{\circ} \mathrm{C}$ had the consistency of a liquid that solidified into a gel-like mass. Samples pre-treated at $150{ }^{\circ} \mathrm{C}$ and $140{ }^{\circ} \mathrm{C}$ appeared more like a dough. Table 1 lists the untreated and pre-treated samples from both pre-treatments and their nomenclature.

\subsubsection{Assessment of the pre-treated samples}

The pre-treated and untreated samples were characterized and evaluated using a scanning electron microscope 
Table 1 Pre-treatment conditions and sample nomenclature

\begin{tabular}{|c|c|c|c|}
\hline Pre-treatment & Pre-treatment temperature $\left({ }^{\circ} \mathrm{C}\right)$ & Humidity conditions & Sample \\
\hline None & - & - & CS \\
\hline- & - & - & Gelatin \\
\hline \multirow[t]{8}{*}{ Extrusion } & 100 & \multirow[t]{4}{*}{ Dry } & E100D \\
\hline & 130 & & E130D \\
\hline & 150 & & E150D \\
\hline & 170 & & E170D \\
\hline & 100 & \multirow[t]{4}{*}{ Wet } & E100W \\
\hline & 130 & & E130W \\
\hline & 150 & & E150W \\
\hline & 170 & & E170W \\
\hline \multirow[t]{3}{*}{ Hydrothermal treatment } & 140 & \multirow[t]{3}{*}{-} & $\mathrm{H} 140$ \\
\hline & 150 & & $\mathrm{H} 150$ \\
\hline & 170 & & $\mathrm{H} 170$ \\
\hline
\end{tabular}

(SEM) and the methods differential scanning calorimetry (DSC), digestibility by trypsin and collagenase and solubility in water.

2.2.2.1 Scanning electron microscope (SEM) The surfaces and fibres of the pre-treated samples and untreated chromium shavings were investigated using an SEM (FEI QUANTA FEG 250). The images obtained with this method were compared visually with the untreated sample.

2.2.2.2 Differential scanning calorimetry (DSC) Using DSC, the enthalpy of the denaturation process was evaluated and it was checked whether the samples have already been denatured or not. Enthalpy represents the necessary energy to break down the hydrogen bonds that stabilize the triple helix. Thermal profiles in fully hydrated state of the pre-treated samples and chromium shavings were taken at a temperature between 0 and $130^{\circ} \mathrm{C}$ using DSC (DSC 1 STAR $^{\mathrm{e}}$ System Mettler Toledo) to assess thermal changes as a function of input temperature. As the denaturation temperature of collagen varies depending on the $\mathrm{pH}$ [47], the $\mathrm{pH}$ was adjusted in advance to the value 7 by washing the samples with a $\mathrm{KH}_{2} \mathrm{PO}_{4} / \mathrm{K}_{2} \mathrm{HPO}_{4}$ buffer solution.

2.2.2.3 Enzyme assays Enzymes break down peptide bonds in the backbone of the structure, a process similar to the actual hydrolysis in anaerobic digestion. The enzyme assays are based on the measurement of the degradation degree of the samples. As the non-denatured collagen is stable to enzymatic degradation [48], it is possible to determine the fraction of the samples, which was denatured during pre-treatment.
The samples were placed into safe-lock microcentrifuge tubes with $\mathrm{NH}_{4} \mathrm{HCO}_{3}$ buffer solution $(\mathrm{pH} 8$ for trypsin and 7.5 for collagenase). Afterwards, the $0.01 \%$ trypsin solution (SIGMA, $1382 \mathrm{U} \mathrm{mL}^{-1}$ ) or the collagenase solution (SIGMA, $\geq 125 \mathrm{CDU} \mathrm{mg}^{-1}$ ) in a concentration of at least $0.2 \mathrm{CDU}$ per $\mathrm{mg}$ of substrate was added at $37^{\circ} \mathrm{C}$. Trypsin assays were carried out for 5 hours and collagenase assays for up to 7 days. For the collagenase assays, a $0.05 \mathrm{M}$ solution of $\mathrm{CaCl}_{2}$ was added to provide Calcium ions required for the enzyme stability and activity, and antibiotic was added to enable a long reaction time. The degradation degree (D) by trypsin or collagenase is the portion of the sample that solubilizes in water after enzymatic treatment and it is represented by Eq. 1:

$$
\mathrm{D}=100-\left(\frac{\mathrm{m}_{\mathrm{f}}}{\mathrm{m}_{0}} \cdot 100\right)
$$

Where $\mathrm{m}_{0}(\mathrm{mg})$ is the onset mass of the samples and $\mathrm{m}_{\mathrm{f}}(\mathrm{mg})$ is the mass after treatment. Both masses were considered on a dry basis.

2.2.2.4 Solubility in water It is known that for identical amino acid compositions, the water solubility of a protein is correlated with the chain length and number of cross-links and can therefore be used to measure the degradation degree of a sample [36]. In this experiment, the parameters expected inside of an anaerobic reactor, such as temperature and $\mathrm{pH}$, are reproduced in order to evaluate the portion of the sample which is promptly soluble.

Approximately $15 \mathrm{mg}$ of the sample on a dry basis were placed into safe-lock microcentrifuge tubes $(2 \mathrm{~mL})$ with $1.5 \mathrm{~mL}$ of water, and its $\mathrm{pH}$ was adjusted between 7 
and 8 with a $\mathrm{NH}_{4} \mathrm{HCO}_{3}$ solution. The samples were stirred in a Thermomixer (Eppendorf) at $300 \mathrm{rpm}$ at $37^{\circ} \mathrm{C}$ for 2 hours. Afterwards, the samples were centrifuged, the supernatant discarded, the centrifugate dried and the dry mass determined. Experiments were run in triplicate and a $\mathrm{t}$-test was conducted to compare means. The solubility in water $(\mathrm{S})$ is represented by Eq. 2:

$$
S=100-\left(\frac{m_{f}}{m_{0}} \cdot 100\right)
$$

Where $\mathrm{m}_{0}(\mathrm{mg})$ is the onset mass of the samples and $\mathrm{m}_{\mathrm{f}}(\mathrm{mg})$ is the mass after treatment. Both masses were considered on a dry basis.

\subsection{Biogas production}

Anaerobic digestion experiments on a laboratory scale were performed to investigate the biogas production potential using the pre-treated samples as substrate. The production potential of untreated chromium shavings and gelatin was also analysed for comparison purposes. Trials were carried out under mesophilic conditions $\left(37 \pm 2{ }^{\circ} \mathrm{C}\right)$ in triplicate or duplicate along with three blanks. The volumes of biogas produced by the blanks (mean of three samples of inoculum without any added substrate) were subtracted from the values obtained for the individual test samples. A t-test was conducted to compare means. The tests were conducted using $65 \mathrm{~mL}$ reactor flasks in batches with agitation (shaking water bath Julabo SW-20C at $150 \mathrm{rpm}$ ). The gas production was monitored on a daily basis with a digital manometer (Leo 3 Keller). As inoculum, mesophilic anaerobic sludge from the municipal sewage treatment plant (Freiberg, Germany) was used. The biogas yield (quantity of generated biogas per quantity of substrate fed) and the biogas formation potential (maximum biogas yield generated from a defined quantity of substrate) are given in standard litres $(273 \mathrm{~K}$ and $1013 \mathrm{hPa})$ per $\mathrm{kg}$ of organic dry matter of the added substrate $\left(\mathrm{L} \mathrm{kg}^{-1}\right)$.

According to VDI 4630 [49], to prevent inhibition in a batch test, substrate should not be overlarge in proportion to the inoculum. The substrate to inoculum ratio to be observed is represented by Eq. 3:

$$
\mathrm{S} / \mathrm{I} \leq 0.5
$$

Where $\mathrm{S}$ is the organic dry matter of the substrate $(\mathrm{g})$ and $I$ is the organic dry matter of the inoculum in the reactor (g). Batches were tested with a substrate to inoculum ratio approximately equal to 0.5 . A load of approximately $0.15 \mathrm{~g}$ (organic dry matter) of the samples along with $20 \mathrm{~g}$ of inoculum was used in the trials.

The cumulative biogas production curve was described using the sigmoidal function of Gompertz, modified as described by Zwietering et al. [50], to fit the experimental biogas production data. The duration of the lagphase ( $\lambda$, days) and the maximum biogas production rate $\left(\mu_{\mathrm{m}}, \mathrm{L} \mathrm{kg}^{-1}\right.$ days $\left.^{-1}\right)$ were predicted with Eq. 4 .

$$
y=A \exp \left\{-\exp \left(\frac{\mu_{m} \mathrm{e}}{\mathrm{A}}(\lambda-\mathrm{t})+1\right)\right\}
$$

Where $y$ is the cumulative biogas production $\left(\mathrm{L} \mathrm{Kg}^{-1}\right)$, $\mathrm{A}$ is the biogas formation potential $\left(\mathrm{L} \mathrm{kg}^{-1}\right), \mathrm{t}$ is the time (days), and e is Euler's number. The model was fitted using the software SigmaPlot version 13.0.

At the end of the process, the resulting biomass was analysed regarding its $\mathrm{pH}$, water content [42], inorganic matter [43], and chromium oxide content [44] in duplicate. The collagen content was determined through the hydroxyproline content [45] in triplicate. Samples were hydrolysed with hydrochloric acid, oxidized with chloramine $\mathrm{T}$ and then reacted with $\mathrm{p}$-dimethylaminobenzaldehyde to develop a red chromophore.

The microbiological degradation of the substrate at the end of the trials was measured as the microbiological degradation of collagen during anaerobic digestion. The microbiological degradation of collagen (CD) was calculated as represented by Eq. 5:

$$
\mathrm{CD}=100-\left(\frac{\text { Coll }_{\mathrm{f}}}{\text { Coll }_{0}} \cdot 100\right)
$$

Where $\operatorname{Coll}_{0}(\mathrm{~g})$ is the collagen mass at the beginning of the biogas trials (substrate + inoculum) and $\operatorname{Coll}_{\mathrm{f}}(\mathrm{g})$ is the collagen mass measured in the final biomass. Both were considered on a dry basis.

\section{Results and discussion}

This section shows results for the extruded samples and the samples treated hydrothermally. The untreated chromium shavings and gelatin are shown for comparison purposes.

\subsection{Assessment of the pre-treated samples}

Results achieved with the different methods show that pre-treatments were able to denature the chromium shavings and increase their anaerobic degradability. The chromium present in the pre-treated chromium shavings appears not to be toxic for enzymes in the anaerobic digestion.

\subsubsection{Characterization of the pre-treated samples}

The characterization of the pre-treated samples gives important information for the biogas trials. Only organics are capable of producing biogas and, therefore, it is important to quantify the organic and inorganic content of the studied substrates. The characterization of 
the pre-treated shavings, untreated chromium shavings, and gelatin is shown in Table 2.

With the exception of hydrothermal treatment, the water content was reduced by pre-treatments. Part of the non-bonded water of the chromium shavings is evaporated due to the high pre-treatment temperatures resulting in a drop of the pre-treated sample's water content.

The organic matter in the samples remains the same after pre-treatments, about $89 \%$ for chromium shavings. This is important because the organics must be preserved for producing biogas in the anaerobic digestion.

The collagen content is also barely unchanged after pre-treatment. This protein is the main component of the chromium shavings. Only about $12 \%$ of the chromium shavings are a different type of organics, for instance fats. Therefore, collagen is the most important parameter to calculate the substrate degradation after anaerobic digestion.

Almost half of the inorganic part of the samples is chromium oxide. Chromium also remains the same after pre-treatment. Other inorganics in the samples result from the chemicals used in tanneries.

\subsubsection{Scanning electron microscope}

SEM images compare chromium shavings with the different pre-treated samples. Figure 1a shows the untreated chromium shavings. It is possible to see a fibrous structure, the fibrils closely aligned together forming the fibres.

Figure $1 \mathrm{~b}$ and $\mathrm{c}$ show the samples extruded dry at $100^{\circ} \mathrm{C}$ and wet at $170^{\circ} \mathrm{C}$ respectively. The material shows severe damage caused by pre-treatment. A clear fibrous structure cannot be seen on the image anymore, some fibrils are detached from the structure and present random positions. Since the collagen molecules were organized as tissue, the fibres shrink when exposed to the denaturation temperature [48]. Meyer et al. [51] verified similar behaviour with SEM images before. The authors observed a fibrillar structure in the initial collagenous material, a parchment-like raw material from limed cattle hides, but after thermomechanical treatment in an internal mixer this structure disappeared.

The sample treated hydrothermally at $150^{\circ} \mathrm{C}$ (Fig. 1d) shows a highly deteriorated structure. The high temperature, which the leather shavings had been exposed to, leads to a melting process of the fibres as can be seen on the right side (indicated in the image). However, the melting appears to be superficial and randomly positioned fibres are still present. Similarly, for the sample treated hydrothermally at $170^{\circ} \mathrm{C}$ (Fig. 1e) some melting can be seen (indicated in the image) but randomly positioned fibres still represent the core of the sample. The presence of molten areas is a strong indicator that the samples are denatured.

\subsubsection{Differential scanning calorimetry and enzyme assays}

Based on the analytical results of DSC and the degradation degree by trypsin shown in Fig. 2, it is possible to conclude that the triple helical structure of the samples disappeared completely thanks to pre-treatments. After thermal pre-treatment none of the samples showed any melting enthalpy which would correspond to remaining hydrogen bonds that stabilize the triple helix [52].

Trypsin assays show that trypsin can degrade the triple helix more easily if the shavings underwent a pre-

Table 2 Characterization of the pre-treated and untreated samples

\begin{tabular}{|c|c|c|c|c|}
\hline & Water content (\%) & Organic matter (\%) & Collagen content (\%) ${ }^{\mathrm{a}}$ & Chromium content $(\%)^{a, b}$ \\
\hline Gelatin & $90.5 \pm 0.0$ & $99.0 \pm 0.0$ & - & - \\
\hline CS & $19.7 \pm 0.1$ & $88.8 \pm 0.1$ & $77.0 \pm 0.6$ & $4.6 \pm 0.0$ \\
\hline E100W & $45.2 \pm 0.7$ & $88.9 \pm 0.1$ & $72.6 \pm 2.4$ & n.d. \\
\hline E130W & $25.8 \pm 0.2$ & $89.0 \pm 0.1$ & $77.8 \pm 1.1$ & n.d. \\
\hline E150W & $10.6 \pm 0.2$ & $89.1 \pm 0.0$ & $79.1 \pm 0.3$ & n.d. \\
\hline E170W & $6.3 \pm 0.1$ & $88.9 \pm 0.1$ & $76.8 \pm 0.7$ & $4.4 \pm 0.0$ \\
\hline E100D & $15.1 \pm 0.1$ & $88.9 \pm 0.0$ & $74.2 \pm 0.9$ & $4.6 \pm 0.0$ \\
\hline E130D & $4.4 \pm 0.0$ & $88.7 \pm 0.1$ & $75.4 \pm 0.7$ & n.d. \\
\hline E150D & $3.7 \pm 0.1$ & $88.8 \pm 0.1$ & $74.5 \pm 1.0$ & n.d. \\
\hline E170D & $2.5 \pm 0.1$ & $88.9 \pm 0.1$ & $73.0 \pm 1.7$ & n.d. \\
\hline $\mathrm{H} 140$ & $83.1 \pm 0.1$ & $88.7 \pm 0.1$ & $73.7 \pm 1.3$ & $4.4 \pm 0.0$ \\
\hline $\mathrm{H} 150$ & $83.6 \pm 0.1$ & $88.9 \pm 0.2$ & $74.7 \pm 0.3$ & $4.4 \pm 0.0$ \\
\hline $\mathrm{H} 170$ & $85.3 \pm 0.3$ & $89.0 \pm 0.0$ & $76.6 \pm 1.2$ & $4.3 \pm 0.0$ \\
\hline
\end{tabular}

${ }^{\mathrm{a}}$ Dry basis; mean \pm standard deviation, $n=3$

${ }^{\mathrm{b}}$ Measured as chromium oxide

n.d. Not determined 


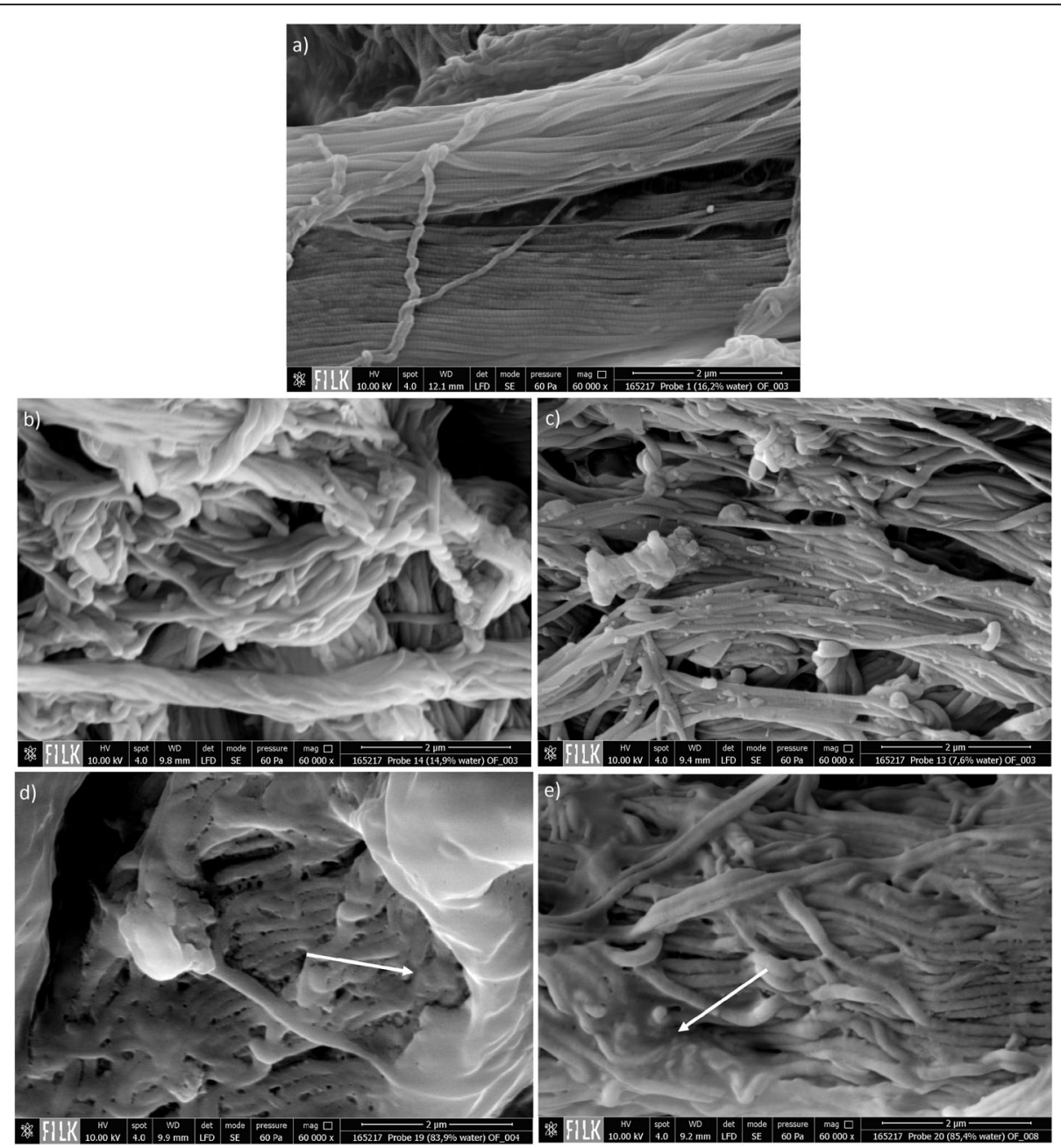

Fig. 1 SEM images of CS (a), E100D (b), E100W (c), H150 (d), H170 (e) (60,000× magnification)

treatment. As trypsin was able to degrade the chromium shavings, which contain more than $4 \%$ of chromium, chromium in this quantity is probably not toxic for trypsin. This implies that the samples will probably not be toxic for the enzymes in the anaerobic digestion.

Extrusion allows for increasing susceptibility of the chromium shavings to degradation by trypsin after five hours from $6.7 \pm 0.4 \%$ up to a maximum of $35.2 \pm 0.4 \%$ for the sample extruded wet at $170^{\circ} \mathrm{C}$. Results showed an increasing tendency of degradation degree with rising extrusion temperature. The previously moistened extruded samples obtained slightly higher degradation degree for the temperatures $150^{\circ} \mathrm{C}$ and $170^{\circ} \mathrm{C}$. The means of digestibility were compared on the basis of the t-test (Table S2, supplementary material). There was no statistically significant difference between samples extruded dry and wet at $100^{\circ} \mathrm{C}(p=0.057)$, and samples extruded dry and wet at $130^{\circ} \mathrm{C}(p=0.257)$, but there was a difference between samples extruded dry and wet at $150^{\circ} \mathrm{C}$ $(p=0.010)$, and samples extruded dry and wet at $170^{\circ} \mathrm{C}$ $(p=0.004)$. The comparison between the samples extruded dry at $100{ }^{\circ} \mathrm{C}$ and wet at $170{ }^{\circ} \mathrm{C}$, which represent extremes of the extrusion pre-treatment, showed a statistically significant difference $\left(p=5.10^{-6}\right)$.

The samples treated hydrothermally showed a clear increase in degradation degree by trypsin with rising temperatures. The sample pre-treated at $170{ }^{\circ} \mathrm{C}$ was highly accessible for trypsin reaching the highest degradation level among the studied samples, $90.3 \pm 0.8 \%$.

Results of the collagenase assays are shown in Fig. 3. The chromium shavings and the shavings extruded dry at $100^{\circ} \mathrm{C}$ were tested for degradation degree by collagenase to evaluate if this enzyme, capable of destabilizing collagen [48], would be more effective to degrade untreated and pretreated shavings. The Clostridium histolyticum has the ability to produce collagenase and belongs to the bacteria clostridia, the main bacteria found in sludge [53]. Clostridium histolyticum is probably present in the medium producing collagenase. Therefore, this enzyme could play an important role in the degradation of the studied substrates. 

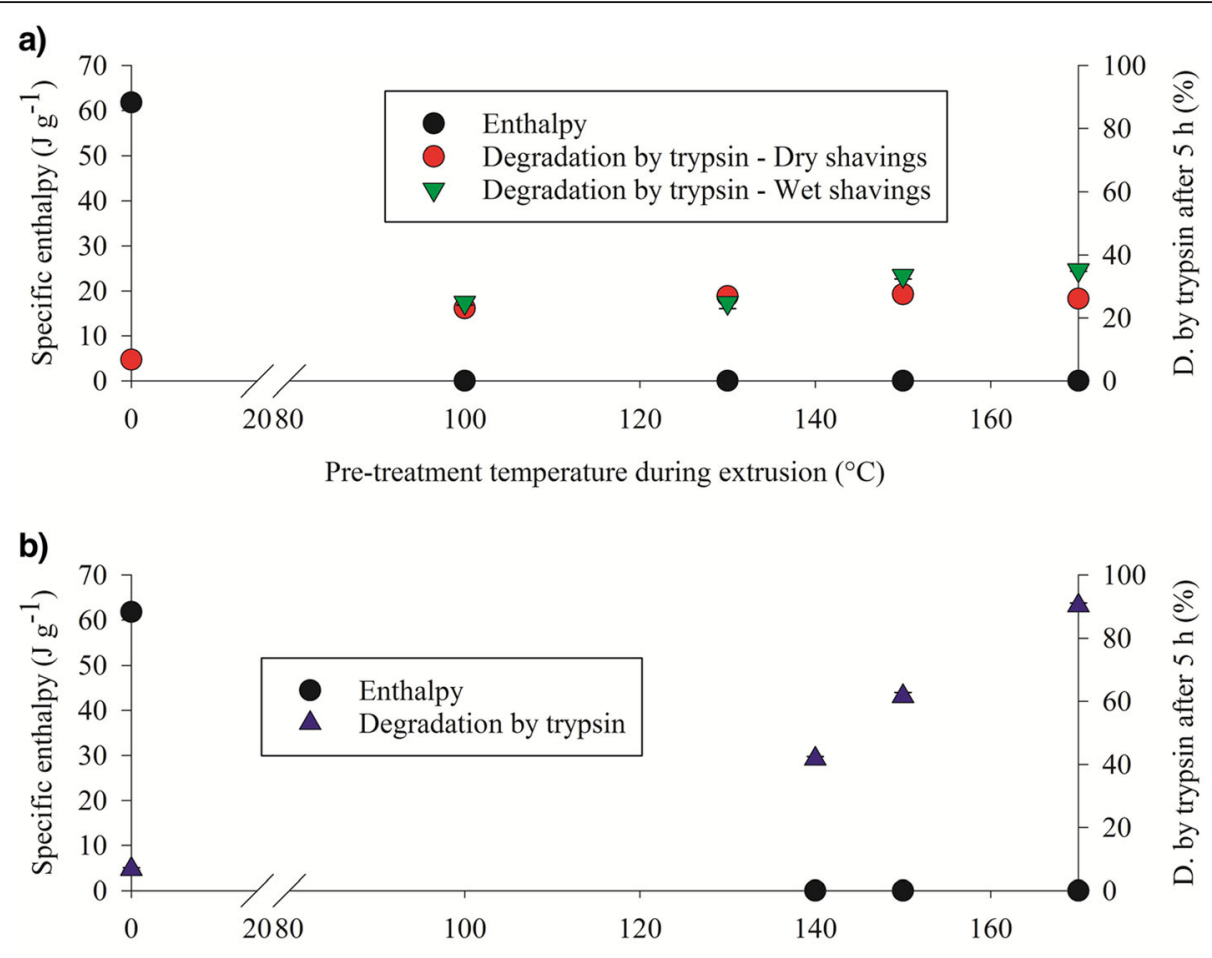

Pre-treatment temperature during hydrothermal treatment $\left({ }^{\circ} \mathrm{C}\right)$

Fig. 2 Enthalpy of denaturation and degradation by trypsin of extruded shavings (a), shavings treated hydrothermally (b), and CS

Even with longer contact times between substrate and enzyme, collagenase did not result in effective degradation of the untreated chromium shavings. Figure 3 shows that degradation of the untreated shavings reached a value of about $12 \%$ after one day and it remains the same after seven days. Results published by Covington [3] also suggest that degradation of chromium leather by proteases is difficult. It was possible only with an abnormally high concentration of enzyme, $\mathrm{pH}$ close to 9 , and temperature close to

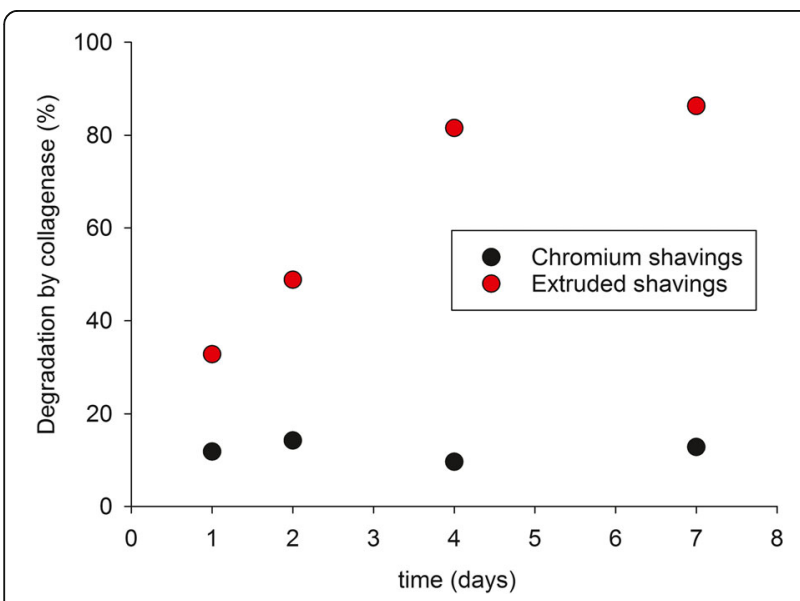

Fig. 3 Degradation degree by collagenase of CS and E100D as a function of time $50^{\circ} \mathrm{C}$. Degradation of the shavings extruded dry at $100^{\circ} \mathrm{C}$ increased linearly with the contact time, reaching up to $86 \%$ of degradation after seven days.

Pre-treatment of the chromium shavings was necessary to enable its degradation degree by collagenase, which happens slowly. Meyer [48] agrees that a pre-treatment can ease the enzymatic degradation. The author tested the degradation of porcine hide with and without synthetic crosslinks (tanning effect accomplished by hexamethylendiisocyanate) by enzymes and concluded that the synthetic crosslinks suppressed the enzymatic action of all enzymes tested. Degradation of the tanned structure was only possible when collagen was denatured (pre-treated by heat) and collagenase was much more effective to degrade it than trypsin.

All samples were completely denatured by the pretreatments tested. Thus, they were more susceptible to enzymatic degradation than the untreated chromium shavings. The higher the pre-treatment temperature the easier degradable the sample by trypsin. The chromium in the quantity present in the studied materials was not toxic to trypsin and collagenase. Consequently, it appears not to be toxic for the enzymes present in the anaerobic digestion.

\subsubsection{Solubility in water}

Figure 4 shows the results of solubility in water at $37{ }^{\circ} \mathrm{C}$ for the pre-treated samples and the untreated chromium shavings. 


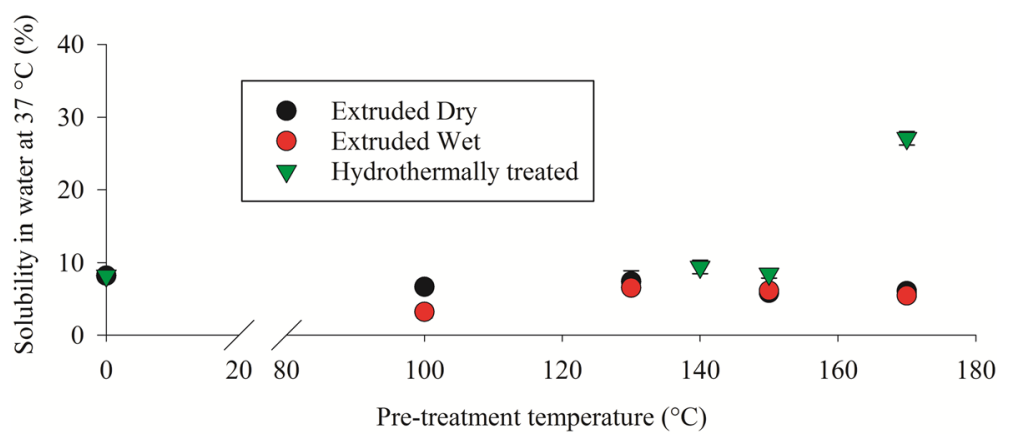

Fig. 4 Solubility in water of extruded shavings, shavings treated hydrothermally, and CS

The extruded samples and chromium shavings had very similar solubility results but, despite the visual similarities, compared to chromium shavings most of the samples showed statistically significant differences in the means of solubility in the t-test. An exception was the sample extruded dry at $130^{\circ} \mathrm{C}$ compared to chromium shavings $(p=0.529)$. However, this is a slight difference only with no practical effect. In general, the solubility values decreased by pre-treatment, probably due to some additional cross-links generated by extrusion [36]. However, this reduction in solubility is very low and has no effect on the biogas production. The values obtained were also very similar for samples treated at the same temperature with or without humidification process. The only samples which showed a significant difference were those extruded dry and wet at $100^{\circ} \mathrm{C}(p=0.019)$.

Extrusion pre-treatment was able to break down hydrogen bonds and open up the triple helix structure without destroying the chains. The chromium shavings were denatured as seen from DSC results. However, extrusion was not able to generate gelatin and, consequently, it was not able to increase solubility in water. The transformation of the collagen-based materials into gelatin depends on exposing the material to a temperature higher than the denaturation temperature and breaking down several bonds to tear apart the triple helix structure. Extrusion pre-treatment uses high temperatures and mechanical forces to degrade the samples. Probably, the contact time of the chromium shavings with the heated extruder, approximately three minutes, was not long enough to transfer the collagen molecules into gelatin chains but it was capable of shrinking them causing the small reduction in solubility.

The solubility of the samples treated hydrothermally can be related to the fibrous structure of the samples and the reduction of protein chain lengths. The sample treated hydrothermally at $170^{\circ} \mathrm{C}$, which was liquid after pre-treatment at $170{ }^{\circ} \mathrm{C}$, showed the highest solubility after pre-treatment among the studied samples (27.1 \pm $0.9 \%$ at $37^{\circ} \mathrm{C}$ ). However, compared to completely soluble gelatin, this value is still low. Therefore, the collagen was not transferred into gelatin. The solubility values of samples treated hydrothermally at $140^{\circ} \mathrm{C}$ and $150^{\circ} \mathrm{C}$ showed no statistically significant difference compared to chromium shavings for which the t-test was applied ( $p=$ 0.197 and $p=0.640$, respectively). The melting of the structure caused by hydrothermal treatment was superficial and the samples still show a partially fibrous structure.

In general, pre-treatments did not affect the solubility in water of the chromium shavings. An exception were the chromium shavings treated hydrothermally at $170^{\circ} \mathrm{C}$, samples which showed molten areas in the SEM image (Fig. 1e). However, solubility in water was low compared to soluble gelatin.

\subsection{Biogas production}

Biogas production results show the advantages of digesting pre-treated chromium shavings compared to chromium shavings without pre-treatment. In batch trials production starts earlier and the reduction of waste (microbiological degradation) is more effective.

The biogas yield was measured in batch tests with chromium shavings (untreated leather shavings), pretreated samples, and gelatin (denatured collagen). Samples were exposed to anaerobic digestion with a substrate to inoculum ratio of approximately 0.5 to investigate their biogas formation potential according to VDI 4630 [49]. A load of approximately $0.15 \mathrm{~g}$ (organic dry matter) of the samples along with $20 \mathrm{~g}$ of inoculum was used in the trials. The modified Gompertz model (MGM) was used to fit the experimental data. Parameters of biogas production from the modified Gompertz equation are shown in Table S3 of the supplementary material. All reactors were agitated.

The biogas yield did not significantly differ between the samples in the three clusters - extruded dry, extruded wet, and treated hydrothermally (Fig. 5b, d, and c). In all clusters, there was no difference after the eighth day of anaerobic digestion. Biogas production was 

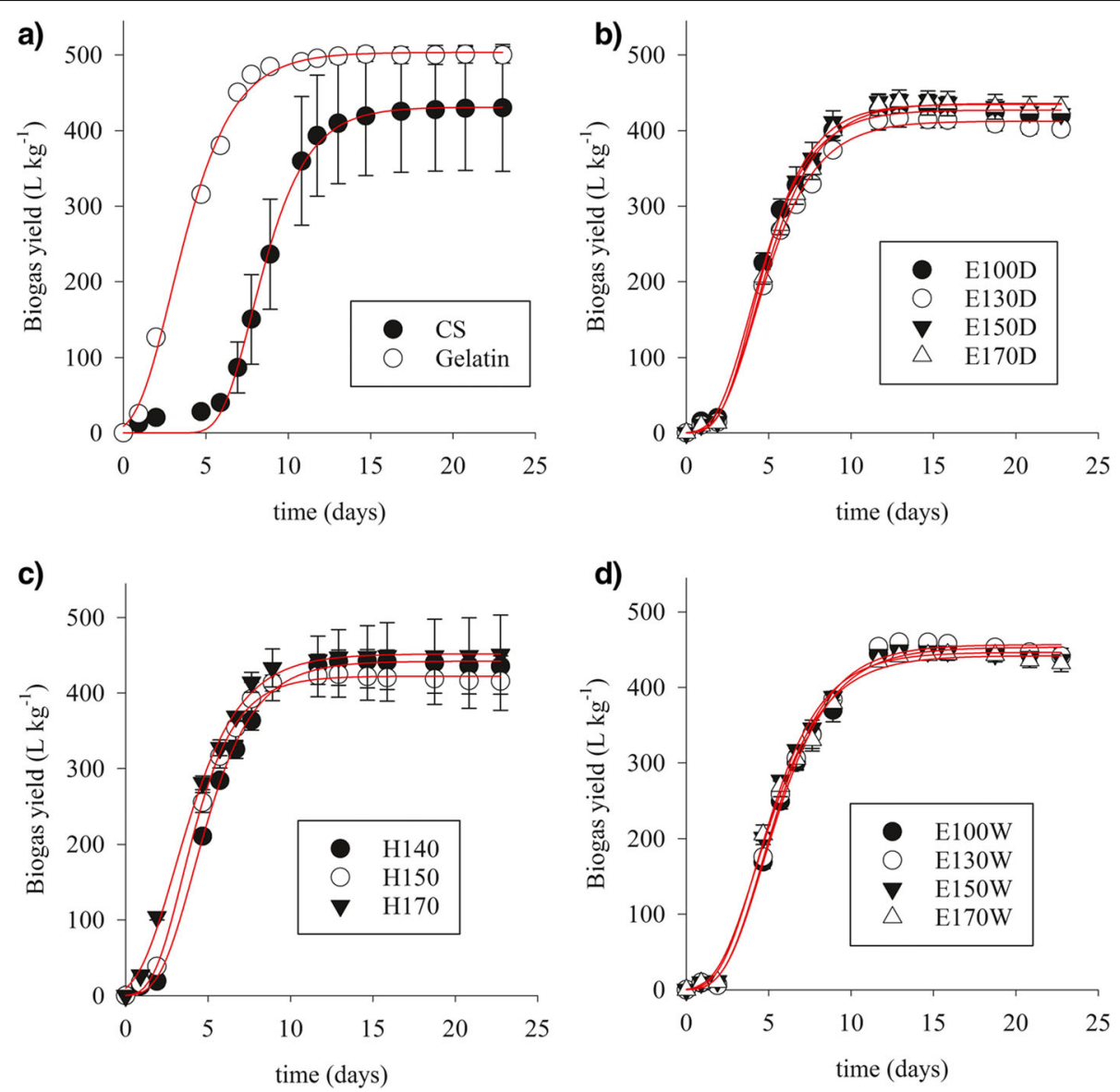

Fig. 5 Cumulative biogas production and MGM (red line) for CS and gelatin (a), samples extruded dry (b) treated hydrothermally (c) and extruded wet (d)

observed immediately after starting the anaerobic reactor. The shape of the chromium shavings curve indicates a retarded microbiological degradation (Fig. 5a). Agustini et al. [24] also showed a similar degradation behaviour in batch trials when studying biogas production with chromium shavings. This is the case when the substrate is difficult to degrade [49].

The modified Gompertz model has been widely used in the simulation of biogas and methane production results [54-57]. This model can predict the lag-phase of the process, a period associated with the hydrolysis of the substrate in the digester. For all substrates tested, the coefficient of determination $\left(R^{2}\right)$ is higher than 0.99 indicating that the modified Gompertz model fitted the experimental data well. The reactors with samples extruded dry and wet showed very similar behaviour. Extrusion pre-treatment reduced the lag-phase of the biogas production $(\lambda)$ from six days to two days compared to chromium shavings. The reactors with samples treated hydrothermally showed even better results. The lag-phase was reduced to two days or even one day, a reduction of four to five days, compared to chromium shavings. Hydrolysis of the pre-treated samples resembled that of gelatin to a much larger degree than that of chromium shavings. Therefore, the more complex the structure of collagen, the later biogas production starts.

Pre-treatments did not increase the maximum biogas production rate $\left(\mu_{\mathrm{m}}\right)$. Results for the pre-treated samples are between 69.8 and $87.4 \mathrm{~L} \mathrm{~kg}^{-1}$ days ${ }^{-1}$, while the chromium shavings showed a value of $83.8 \mathrm{~L} \mathrm{~kg}^{-1}$ days ${ }^{-1}$. All the substrate, which was effectively hydrolysed in the hydrolysis phase or in a pre-treatment, can be processed at the same rate in the next stages of anaerobic digestion.

The biogas formation potential of all pre-treated samples was very similar, between 416 and $460 \mathrm{~L} \mathrm{~kg}^{-1}$ (Table S4, supplementary material). ANOVA showed no statistically significant differences $(p=0.843)$ (Table S2, supplementary material). The highest biogas formation potential was reached by the sample extruded wet at $130{ }^{\circ} \mathrm{C}, 460 \pm 6 \mathrm{~L} \mathrm{~kg}^{-1}$. Unfortunately, measuring devices for analysing the composition of biogas (percentage methane and carbon dioxide) were not available. However, part of the samples was tested in a previous work for continuous production of biogas. The production of 
methane was less than $40 \%$ at the beginning of the digestion but after a few days, it increases reaching up to $68 \%$ [58].

The chromium shavings showed a similar biogas formation potential compared to the pre-treated samples, but the untreated sample needed a longer period of time to be degraded than the pre-treated samples. Considering the values found in the enzyme assays with trypsin and collagenase, the chromium shavings were expected to be less degraded and generate less biogas than the pre-treated samples. Probably hydrolysis of chromium shavings, which are not previously denatured, involves several enzymes working simultaneously to degrade them and this requires some days causing a lag-phase. Other authors tested anaerobic digestion of chromium leather and found lower biogas yields. For instance, Priebe et al. [25] reached a biogas yield of around $162 \mathrm{~L} \mathrm{~kg}^{-1}$ testing the degradation of chromium-tanned leather shavings in different biotas and Agustini [26] found a cumulative biogas production of around $30 \mathrm{~L} \mathrm{~kg}^{-1}$ studying the degradation of chromiumtanned leather shavings using sludge of wastewater treatment as inoculum.

Pre-treated samples did not reach the same biogas formation potential as gelatin $\left(532 \mathrm{~L} \mathrm{~kg}^{-1}\right)$. Even though pre-treated samples are completely denatured, they still have a long chain structure which needs to be broken down, a process gelatin already underwent. Therefore, presumably microorganisms will need much more energy to degrade pre-treated leather shavings than gelatin. In addition, anaerobic digestion of gelatin did not reach the theoretical biogas yield of $796 \mathrm{~L} \mathrm{~kg}^{-1}$ calculated for bovine hide collagen $[49,59]$. The value for the biogas formation potential of gelatin is also lower than that found for casein or blood as protein-rich substrates [60], meaning that collagen-rich samples are expected to yield less biogas compared to other proteinaceous materials. An explanation for this could be that the collagen chain itself is a substrate which needs much effort to be degraded. This could be investigated in future by analysing intermediates, not only organic acids but also amino acids or oligo-peptides, which can result from degradation processes.

At the beginning of the trials, the collagen content of the combination of inoculum and substrate was determined. Using this value and Eq. 5, it was possible to calculate the microbiological collagen degradation of the substrates achieved by the anaerobic process. Table S4 of the supplementary material shows the characterization of the final biomass and compares the collagen content at the end of the trials to the collagen content at the beginning resulting in the microbiological collagen degradation.

During anaerobic digestion of chromium shavings the collagen content only decreased to $4.7 \%$ while in the pre-treated sample it was reduced almost to zero. The microbiological collagen degradation above $97 \%$ in every case shows a clear difference between pre-treated and untreated samples (77.2\%). These results indicate that with regard to anaerobic digestion chromium shavings are a complex substrate and pre-treatment is very important to assure high microbiological degradation. However, surprisingly the pre-treated sample did not reach the same biogas formation potential as gelatin.

The high microbiological collagen degradation of the pre-treated chromium shavings indicates that the chromium content of up to $1.3 \%$ (measured as chromium oxide) did not affect the microbiological degradation of the samples. In a previous work [61], higher chromium contents in the biomass were detected (of up to $3.6 \%$ ) and the anaerobic process was not affected. In this work, the characterization of the final biomass revealed that chromium is present in concentrations between 40 and 170 $\mathrm{mg} \mathrm{L}^{-1}$ of $\mathrm{Cr}^{3+}$ in the bioreactors; therefore, the concentration of chromium in the biomass did not reach toxic values found by Alkan [21]. Previously, Agustini et al. [41] also tested the anaerobic digestion of chromium leather shavings in batch reactors reaching a concentration of almost $6 \mathrm{mg} \mathrm{L}^{-1}$ of $\mathrm{Cr}^{3+}$, which did not prevent biogas and methane production. According to the European Council directive 86/278/EEC [62, 63], the limit values for chromium concentrations in sludge for use in agriculture are 1000 to $1750 \mathrm{mg} \mathrm{kg}^{-1}$ of dry matter. Chromium is present in concentrations of 1232 to $9389 \mathrm{mg} \mathrm{kg}^{-1}$ of dry matter in the biomass; therefore, the use of the final biomass in agriculture is not possible without pre-treatment to remove chromium. Extraction and recycling of chromium from the final biomass produced in the reactors must be further studied. Moreover, the $\mathrm{pH}$ of the biomass after digestion was very stable, always between 8 and 8.5 , highlighting the stability of the process.

Therefore, pre-treatments were important to partially replace the hydrolysis step of the biogas production, represented by the lag-phase, and assure a reduction of the final waste. The reduction of the lag-phase in batch reactors is also an important result for transferring this technology to continuous reactors. In a continuous process, it would be possible to increase the daily substrate load or, in contrast, the reactor volume for a given loading rate could be decreased leading to a more economical process. This was already seen in a previous work [58], in which the daily substrate load could be increased by 40 to $50 \%$ through pre-treatment of the chromium shavings. This shows that using these pre-treatments would be beneficial for the production of biogas from chromium shavings.

\section{Conclusion}

Two principally different pre-treatments, extrusion and hydrothermal treatment, were carried out to denature the stable collagen structure of chromium shavings and 
enhance anaerobic digestion using them as substrate. To measure digestibility, it was possible to degrade the pretreated shavings with trypsin by more than $90 \%$ with regard to the samples treated hydrothermally and 35\% for the extruded samples. Extrusion pre-treatment could also increase the degradation degree by collagenase from $12 \%$ to $86 \%$. Differential scanning calorimetry results showed that the hydrogen bonds that stabilize the collagen structure to enzymatic degradation were broken down. Therefore, evaluation of the pre-treated samples showed that all of them were denatured and that chromium present in the quantity of $4 \%$ in shavings, measured as chromium oxide, is probably not toxic for enzymes in the anaerobic digestion.

In batch tests, extrusion pre-treatment resulted in a decrease of four days concerning the lag-phase for the biogas production of the chromium shavings. Hydrothermal treatment showed a decrease of four to five days initiating biogas production already the day after starting the tests. With pre-treatment the collagen content was reduced more intensively than without pre-treatment and it was possible to reach a microbiological collagen degradation of $99.3 \%$ for the pre-treated samples.

Results hitherto obtained show that pre-treatments applied for chromium leather shavings can allow enzymatic attack and increase the efficiency of the biogas production. The process started earlier and microbiological waste degradation was enhanced. The simple application of a pre-treatment can increase the feasibility of producing energy with chromium leather waste. If implemented, this process can reduce costs for energy consumption and disposal of waste, eliminate solid waste, and reduce greenhouse gas emissions from the microbiological degradation of tannery waste.

\section{Supplementary information}

Supplementary information accompanies this paper at https://doi.org/10. 1186/s42825-020-00028-x.

Additional file 1. Degradation degree of collagen and t-test.

Additional file 2. Parameters of biogas production from the modified Gompertz equation and biomass characterization after digestion and biogas formation potential.

\footnotetext{
Abbreviations

A: Biogas formation potential; CD: Microbiological degradation of collagen; CS: Chromium Shavings; D: Degradation degree by trypsin or collagenase; DSC: Differential scanning calorimetry; E100D: Shavings extruded dry at $100^{\circ} \mathrm{C}$; E130D: Shavings extruded dry at $130^{\circ} \mathrm{C}$; E150D: Shavings extruded dry at $150^{\circ} \mathrm{C}$; E170D: Shavings extruded dry at $170^{\circ} \mathrm{C} ; \mathrm{E} 100 \mathrm{~W}$ : Shavings extruded wet at $100^{\circ} \mathrm{C}$; E130W: Shavings extruded wet at $130^{\circ} \mathrm{C}$; E150W: Shavings extruded wet at $150^{\circ} \mathrm{C}$; E170W: Shavings extruded wet at $170^{\circ} \mathrm{C} ; \mathrm{H} 140$ : Shavings treated hydrothermally at $140^{\circ} \mathrm{C} ; \mathrm{H} 150$ : Shavings treated hydrothermally at $150^{\circ} \mathrm{C} ; \mathrm{H} 170$ : Shavings treated hydrothermally at $170^{\circ} \mathrm{C} ; \mathrm{m}_{0}$ : Onset mass of the samples; $\mathrm{m}_{\mathrm{f}}$ : Mass after treatment; MGM: Modified Gompertz model; $\mathrm{R}^{2}$ : Coefficient of determination; S: Solubility in water; SEM: Scanning electron microscope; S/I: Substrate to
}

inoculum ratio; t: Time; $y$ : Cumulative biogas production; $\lambda$ : Lag-phase of the biogas production; $\mu_{m}$ : Maximum biogas production rate

\section{Acknowledgements}

This study was financed by the German Academic Exchange Service (DAAD) and the Coordenação de Aperfeiçoamento de Pessoal de Nível Superior -

Brasil (CAPES) - Finance Code 001

\section{Authors' contributions}

CSG contributed to the data collection, data analysis and was a major contributor in writing the manuscript. JR contributed to the manuscript preparation. MM contributed to the data analysis and manuscript preparation. The authors read and approved the final manuscript.

\section{Funding}

Not applicable.

Availability of data and materials

All data generated or analysed during this study are included in this published article and its supplementary information files.

\section{Competing interests}

The authors declare that they have no competing interests.

\section{Author details}

${ }^{1}$ Forschungsinstitut für Leder und Kunststoffbahnen (FILK) gGmbH, Meißner Ring 1-5, 09599 Freiberg, Germany. ${ }^{2}$ Dynamik und Betrieb technischer Anlagen, TU Berlin, Straße des 17. Juni 135, 10623 Berlin, Germany.

Received: 16 March 2020 Accepted: 16 June 2020

Published online: 27 June 2020

\section{References}

1. Verband der Deutschen Lederindustrie. VDL-Statistik Nutztierbestand und Rohwarenerzeugung 2018 in Deutschland, Europa und wichtigen Drittländern. Frankfurt am Main: VDL; 2019.

2. Chakraborty R. Ecofriendly solid waste management in the leather industry. Environ Biotechnol newsletter India: University of Kalyani. 2003;3:2.

3. Covington AD. Tanning chemistry: the science of leather. Cambridge: The Royal Society of Chemistry; 2009.

4. Pati A, Chaudhary R, Subramani S. A review on management of chrometanned leather shavings: a holistic paradigm to combat the environmental issues. Environ Sci Pollut Res. 2014;21:11266-82.

5. Mu C, Lin W, Zhang M, Zhu Q. Towards zero discharge of chromiumcontaining leather waste through improved alkali hydrolysis. Waste Manag. 2003;23:835-43.

6. International Union of Leather Technologists and Chemists Societies. IUE4 assessment for chromium containing waste from the leather industry; 2018. http://www.iultcs.org/pdf//UE_4.pdf. Accessed 08 Jul 2019.

7. Kalyanaraman C, Kameswari KSB, Rao JR. Studies on enhancing the biodegradation of tannins by ozonation and Fenton's oxidation process. J Ind Eng Chem. 2015;25:329-37.

8. Trommer B, Kellert H-J. Comparison of tanning methods from an ecological viewpoint (part 1). Leather. 1999:201(12):37-44.

9. Deublein D, Steinhauser A. Biogas from waste and renewable resources: an introduction. Weinheim: Wiley-VCH; 2008.

10. Murphy JD, Thamsiriroj T. Fundamental science and engineering of the anaerobic digestion process for biogas production. In: Wellinger A, Murphy J, Baxter D, editors. The biogas handbook. Cambridge: Woodhead Publishing Limited; 2013. p. 104-30.

11. Shanmugam $P$, Horan NJ. Optimising the biogas production from leather fleshing waste by co-digestion with MSW. Bioresour Technol. 2009;100:4117-20.

12. Kameswari KSB, Kalyanaraman C, Thanasekaran K. Evaluation of various pretreatment processes on tannery sludge for enhancement of soluble chemical oxygen demand. Clean Techn Environ Policy. 2014;16:369-76.

13. Banu JR, Kaliappan S. Treatment of tannery wastewater using hybrid upflow anaerobic sludge blanket reactor. J Environ Eng Sci. 2007:6:415-21.

14. Kameswari KSB, Kalyanaraman C, Thanasekaran K. Effect of ozonation and ultrasonication pretreatment processes on co-digestion of tannery solid wastes. Clean Techn Environ Policy. 2011;13:517-25. 
15. Kameswari KSB, Kalyanaraman C, Porselvam S, Thanasekaran K. Optimization of inoculum to substrate ratio for bio-energy generation in co-digestion of tannery solid wastes. Clean Techn Environ Policy. 2012;14:241-50.

16. Thangamani A, Rajakumar S, Ramanujam RA. Anaerobic co-digestion of hazardous tannery solid waste and primary sludge: biodegradation kinetics and metabolite analysis. Clean Techn Environ Policy. 2010;12:517-24.

17. Kameswari KSB, Kalyanaraman C, Umamaheswari B, Thanasekaran K. Enhancement of biogas generation during co-digestion of tannery solid wastes through optimization of mix proportions of substrates. Clean Techn Environ Policy. 2014;16:1067-80.

18. Kameswari KSB, Kalyanaraman C, Thanasekaran K. Optimization of organic load for co-digestion of tannery solid waste in semi-continuous mode of operation. Clean Techn Environ Policy. 2015;17:693-706.

19. Ravindranath E, Chitra K, Porselvam S, Srinivasan SV, Suthanthararajan R. Green energy from the combined treatment of liquid and solid waste from the tanning industry using an upflow anaerobic sludge blanket reactor. Energy Fuel. 2015;29:1892-8.

20. Thangamani A, Parthiban L, Rangasamy P. Two-phase anaerobic digestion model of a tannery solid waste: experimental investigation and modeling with ANFIS. Arab J Sci Eng. 2015;40:279-88.

21. Alkan U, Anderson GK, Ince O. Toxicity of trivalent chromium in the anaerobic digestion process. Water Res. 1996;30(3):731-41.

22. Dhayalan K, Fathima NN, Gnanamani A, Rao JR, Nair BU, Ramasami T. Biodegradability of leathers through anaerobic pathway. Waste Manag. 2007;27:760-7

23. Ferreira MJ, Almeida MF, Pinho SC, Santos IC. Finished leather waste chromium acid extraction and anaerobic biodegradation of the products. Waste Manag. 2010;30:1091-100.

24. Agustini C, Neto W, Costa M, Gutterres M. Biodegradation and biogas production from solid waste of tanneries. Novo Hamburgo: XXXIII IULTCS Congress; 2015.

25. Priebe GPS, Kipper E, Gusmão AL, Marcilio NR, Gutterres M. Anaerobic digestion of chrome-tanned leather waste for biogas production. J Clean Prod. 2016;129:410-6.

26. Agustini C, Costa M, Gutterres M. Biogas production from tannery solid wastes - scale-up and cost saving analysis. J Clean Prod. 2018;187:158-64.

27. Gomes CS, Repke J-U, Meyer M. Different pre-treatments of chrome tanned leather waste and their use in the biogas production. Chennai: XXXIV IULTCS Congress; 2017

28. Heidemann E. Fundamentals of leather manufacturing. Darmstadt: Eduard Roether KG; 1993.

29. Hulmes DJS. Collagen diversity, synthesis and assembly. In: Fratzl P, editor Collagen: structure and mechanics. New York: Springer; 2008. p. 15-48.

30. Wess TJ. Collagen fibrillar structure and hierarchies. In: Fratzl P, editor. Collagen: structure and mechanics. New York: Springer; 2008. p. 49-80.

31. Avery NC, Bailey AJ. Restraining cross-links responsible for the mechanical properties of collagen fibers: natural and artificial. In: Fratzl P, editor. Collagen: structure and mechanics. New York: Springer; 2008. p. 81-110.

32. Mata-Alvarez J, Dosta J, Romero-Güiza MS, Fonoll X, Peces M, Astals S. A critical review on an aerobic co-digestion achievements between 2010 and 2013. Renew Sust Energ Rev. 2014:36:412-27.

33. Mata-Alvarez J, Macé S, Llabrés P. Anaerobic digestion of organic solid wastes. An overview of research achievements and perspectives. Bioresour Technol. 2000;74:3-16.

34. Penaud V, Delgenes JP, Moletta R. Thermo-chemical pretreatment of a microbial biomass: influence of sodium hydroxide addition on solubilization and anaerobic biodegradability. Enzym Microb Technol. 1999;25:258-63.

35. Schroepfer M, Meyer M. DSC investigation of bovine hide collagen at varying degrees of crosslinking and humidities. Int J Biol Macromol. 2017;103:120-8.

36. Klüver E, Meyer M. Preparation, processing, and rheology of thermoplastic collagen. J Appl Polym Sci. 2013;128(6):4201-11.

37. Pillai $P$, Archana G. A novel process for biodegradation and effective utilization of chrome shavings, a solid waste generated in tanneries, using chromium resistant Bacillus subtilis P13. Process Biochem. 2012:47:2116-22.

38. Katsifas EA, Giannoutsou E, Lambraki M, Barla M, Karagouni AD. Chromium recycling of tannery waste through microbial fermentation. J Ind Microbiol Biotechnol. 2004;31:57-62.

39. Mizuse T, Mitzuse M, Yoneda H, Nakayasu T. "Process for treating tanned leather wastes and apparatus therefor", EP1529850A1. https://patentimages. storage.googleapis.com/3a/e7/ef/eccaa4b752856b/EP1529850A1.pdf. Accessed 3 Dec 2019.
40. Pati A, Chaudhary R. Studies on the generation of biogas from collagen hydrolysate obtained from chrome shavings by alkaline hydrolysis: a greener disposal method. Res J Recent Sci. 2013;2:234-40.

41. Agustini CB, Meyer M, Da Costa M, Gutterres M. Biogas from anaerobic codigestion of chrome and vegetable tannery solid waste mixture: influence of the tanning agent and thermal pretreatment. Process Saf Environ. 2018; 118:24-31.

42. DIN EN ISO 4684. Leather - chemical tests - determination of volatile matter. Berlin: German Institute for Standardization; 2005.

43. DIN EN ISO 4047. Leather - determination of sulphated total ash and sulphated water-insoluble ash. Berlin: German Institute for Standardization; 1998.

44. DIN EN ISO 5398-1. Leather - chemical determination of chromic oxide content. Berlin: German Institute for Standardization; 2007.

45. Stegemann H. Microdetermination of hydroxyproline with chloramine-T and p-dimethylaminobenzaldehyde. Hoppe Seylers Z Physiol Chem. 1958;311:41.

46. IHD. Tätigkeitsbericht 2006. Görlitz: MAXROI Graphics GmbH; 2007.

47. Schröpfer M. Influences on thermal stability of fibrous collagen - calorimetric investigations. Freiberg: 5th Freiberg Collagen Symposium; 2012.

48. Meyer M. Processing of collagen based biomaterials and the resulting materials properties. Biomed Eng Online. 2019;18:24.

49. VDI 4630. Fermentation of organic materials, characterization of the substrate, sampling, collection of material data, fermentation tests. Düsseldorf: The Association of German Engineers; 2006.

50. Zwietering $\mathrm{MH}$, Jongenburger I, Rombouts FM, Riet KV. Modeling of the bacterial growth curve. Appl Environ Microbiol. 1990;56(6):1875-81.

51. Meyer M, Mühlbach R, Harzer D. Solubilisation of cattle hide collagen by thermo-mechanical treatment. Polym Degrad Stab. 2005;87:137-42.

52. Burjanadze TV, Kisiriya EL. Dependence of thermal stability on the number of hydrogen-bonds in water-bridged collagen structure. Biopolymers. 1982; 21:1695-701.

53. Mclnerney MJ. Anaerobic hydrolysis and fermentation of fats and proteins. In: Zehnder AJB, editor. Biology of anaerobic microorganisms. New York: Wiley; 1988. p. 373-415

54. Li C, Champagne P, Anderson BC. Evaluating and modeling biogas production from municipal fat, oil, and grease and synthetic kitchen waste in anaerobic co-digestions. Bioresour Technol. 2011;102:9471-80.

55. Kafle GK, Kim SH. Effects of chemical compositions and ensiling on the biogas productivity and degradation rates of agricultural and food processing by-products. Bioresour Technol. 2013;142:553-61.

56. Chanakya HN, Khuntia HK, Mukherjee N, Aniruddha R, Mudakavi JR, Thimmaraju P. The physicochemical characteristics and anaerobic degradability of desiccated coconut industry waste water. Environ Monit Assess. 2015;187:772.

57. Kim MJ, Kim SH. Minimization of diauxic growth lag-phase for highefficiency biogas production. J Environ Manag. 2017;187:456-63.

58. Gomes CS, Repke J-U, Meyer M. The effect of various pre-treatment methods of chromium leather shavings in continuous biogas production. Eng Life Sci. 2020;20:79-89.

59. Boyle WC. Energy recovery from sanitary landfills - a review. In: Schlegel HG, Barnea J, editors. Microbial energy conversion. Oxford: Pergamon Press; 1976. p. 119-38.

60. Kovács E, Wirth R, Maróti G, Bagi Z, Rákhely G, Kovács KL. Biogas production from protein-rich biomass: fed-batch anaerobic fermentation of casein and of pig blood and associated changes in microbial community composition. PLoS One. 2013;8(10):e77265.

61. Gomes CS, Repke J-U, Meyer M. Diauxie during biogas production from collagen-based substrates. Renew Energy. 2019;141:20-7.

62. Council directive $86 / 278 / \mathrm{EEC}$ on the protection of the environment, and in particular of the soil, when sewage sludge is used in agriculture. In: Official Journal of the European Communities L181/6. 1986. https://eur-lex.europa.eu/legalcontent/EN/TXT/PDF/?uri=CELEX:31986L0278\&from=EN. Accessed 16 Mar 2020.

63. Proposal for a Council Directive amending in respect of chromium Directive $86 / 278 /$ EEC on the protection of the environment, and in particular of the soil, when sewage sludge is used in agriculture (COM(88) 624 final). In: Official Journal of the European Communities C307/9. 1988. https://eur-lex. europa.eu/legal-content/EN/TXT/PDF/?uri=CELEX:51988PC0624\&from=EN. Accessed 16 Mar 2020

\section{Publisher's Note}

Springer Nature remains neutral with regard to jurisdictional claims in published maps and institutional affiliations. 